DOI https://doi.org/10.36059/978-9934-588-42-6/19-35

\title{
ЛЮДСЬКА ЕКЗИСТЕНЦІЯ У КОНТЕКСТІ РЕЛІГІЙНОЇ ІНТЕРПРЕТАЦІЇ СУСПІЛЬСТВА ТА ВЛАДИ: МЕЖІ ЄВРОПЕЙСЬКОЇ ІМПЛЕМЕНТАЦІЇ
}

\author{
Бліхар В. С., Бліхар М. М.
}

\section{ВСТУП}

Людина часто будує світосприйняття згідно 3 мірою власних цінностей. У цьому сенсі постають актуальними питання про співвідношення релігії та держави під час побудови соціального життя як частини моральної людини загалом та держави як надбудови соціуму. Адже вплив богословського світогляду на традиційні погляди українців щодо побудови демократичної Української держави, безсумнівно, сприятиме не тільки формуванню нового погляду на функції держави, але й подальшому вдосконаленню відносин між державою та церквою, підвищенню функціональності релігійного середовища, утвердженню в українському суспільстві миру, злагоди i взаєморозуміння загалом та духовного розвитку особистості зокрема.

Як свідчить історична наука та релігієзнавство, християнство вже від початку здійснення своєї місії істотно впливає на філософські погляди європейської цивілізації $\mathrm{i}$ навіть тепер деякою мірою спричинюється до творення громадянського суспільства. Проте вивчення його морального впливу ще й досі $\epsilon$ не цілком усвідомлюваним, 3 уваги на секуляризаційну інерцію мислення, сформовану під знаком Просвітництва. Світоглядні ідеї та філософсько-антропологічні погляди святих отців християнської церкви на людину, на іiї соціальне буття $\epsilon$ помітним явищем в історії християнської філософії. Адже, як правило, в будь-якому суспільстві від держави вимагається, щоб уповноважені нею органи мали право застосовувати легалізований примус від імені всього суспільства, підкоряючи членів спільноти встановленим державою правилам, навіть якщо вони суперечать переконанням її громадян. Із цією метою використовується державна влада, апарат держави. Легалізація примусу, насилля 3 боку держави здійснюється відповідно до прийнятого в цьому суспільстві бачення принципів суспільних норм, які встановлює сама ж держава, але які, як передбачається, виражають 
інтереси всього суспільства, схвалені й легітимізовані ним. Окрім того, поширення раціоналізму під впливом значного розвитку науки у XX ст. і затьмарило середньовічні європейські здобутки антропоцентричної філософії, накинувши на них тінь від так званих «темних віків». Просвітницькі настрої, які поширювали тогочасні інтелектуали та освіта, розглядали середньовіччя, у кращому разі, як прелюдію після античності перед iї новим відродженням. Упередженість і зверхність стосувалися також християнства та його світоглядної традиції, що знайшло свій крайній атеїстичний вираз у багатьох філософських теоріях другої половини XIX ст. Очевидно, не випадково саме в радикальній марксистській версії громадянське суспільство засуджено на зникнення із життя разом зі свободою і правами людини.

\section{1. Релігія і держава: європейський філософський дискурс}

В усіх основних світових релігіях, таких як іудаїзм, християнство та іслам, ми знаходимо положення, які виражають і необхідність формування суспільно-політичних чинників (побудови Месією нового суспільства та відкидання старого), і перетворення самої людської особистості на засадах оновленого світу. Вже через тисячу років після виникнення християнства Західна Європа стала християнським суспільством (chretiente), і вплив християнських ідеалів спонукав філософів-богословів до більшої вимогливості у сфері політичного й економічного життя ${ }^{1}$. Проте, як засвідчив історичний процес, лише християнству суджено перетворитися на іманентну духовну форму західного типу людського та громадянського розвитку. Громадянські права людини закріпилися в сучасному світі на рівні конституційних норм, грунтуючись на політичному визнанні універсального значення свободи та гідності людини як особи, історично складається процес формування громадянського суспільства в контексті розвитку західної цивілізації на основі християнських традицій. Отже, європейська цивілізація одержала усвідомлення про вартості свободи і права 3 двох джерел: античного i християнського. Проте в християнському світосприйнятті сенс свободи набув нової інтерпретації і нового універсального значення. Додержуючись слів Тертуліана «вірую, тому що абсурдно є» $\mathrm{i}$ намагаючись пояснити в такий спосіб все раціонально-логічне, християнство передусім поставило питання про

1 Лобье П. де. Социальная доктрина Католической Церкви: опыт воплощения христианского идеала. Брюссель : [б. и.], 1989. 254 с. 
достовірність i правильність строго логічного, раціонального витлумачення буття світу. Виведення на передній план розуміння й пояснення світу віри фактично лише легітимізувало сумнів у вичерпності логічного, раціонального, а, по суті, детерміністичного (за Аристотелем) і лінеарного підходів до значення свободи в житті людини і суспільства. У контексті християнського світорозуміння, очевидно, вперше відбувається зміщення логіки причиновонаслідкового пояснення до логіки інтерпретації, в якій істотна роль відводиться божественному розуму, диву і чудесній дії, утримуючи при цьому загальносилогістичну систему аргументації.

Проблема людської свободи як умови здійснення вільного вибору у всі часи $\epsilon$ актуальною. Її релігійно-філософська інтерпретація має велике значення для формування потенціалу особистості, бо саме вибір $\epsilon$ сутнісною характеристикою індивіда, особливістю його активної життєвої позиції. Екзистенційний розгляд під час здійснення свободи, осмислення християнсько-філософських узагальнень між поняттями «свобода», «вибір» і «відповідальність», безумовно, істотно конкретизує уявлення про людську свободу, уточнює іiі смисл і значення в соціумі. Осмислення проблеми свободи 3 погляду християнських норм збагачує розуміння філософської думки щодо цієї складової частини теорії свободи особистості. Варто зауважити, що свобода, згідно 3 християнськими традиціями, здійснюється покаянням, прощенням, милосердям і вдячністю - діями і словами, що приходять на землю лише завдяки свідомому вибору людини між тим, що вона хоче, і тим, що вона може вчинити. Як зауважує Г. Арендт, «що більше хилиться стрілка в бік катастрофи, то несподіванішою і чудеснішою буває дія в умовах свободи; бо автоматично приходять не порятунок, а катастрофа, яка через це й здається невідворотною» ${ }^{2}$.

Отже, саме християнство кинуло виклик пріоритетові політичного і колективного здійснення людської свободи. Аскеза як винятково індивідуальний шлях самовдосконалення стає умовою сподіваної свободи. Дуже важливим і несподіваним для римського світу стало те, що християнське вчення позбавило імперську владу й соціальність породжуваних ними претензій на божественне походження. Всемогутність імператорів і володарів була назавжди поставлена під сумнів. Людському розумінню відкрилися два типи основ суспільства: церковного i політичного (державного). Досліджувати свободу особистості потрібно як проблему самореалізації індивіда засобами

\footnotetext{
${ }^{2}$ Арендт Г. Між минулим і майбутнім. Київ: Дух і Літера, 2002. С. 180.
} 
вибору його світоглядної і життєвої позиції в ситуації християнського екзистенційного напруження та суспільної діяльнісної активності людини, спрямованої на творчість свободи, адекватної критеріям культури, моралі та відповідальності. Можливість вибору - це наявність вибору в широкій різноманітності мотивів людської діяльності, кожний з яких може бути по-своєму виправданий, залежно від цінностей, пріоритетів, завдань і цілей. Головна небезпека полягає в зіткненні різних «варіантів» правди, різних програм розв'язання проблем, їх інтерпретацій. Часто вільний вибір людини - це здатність до творення свободи, особлива риса зрілої особистості, яка є межею між умінням користуватися вже наявними дарами свободи і потребою в іiі здійсненні. Загалом, Християнська церква вважає, що держава виникає не безпосередньо 3 волі Божої, а 3 наслідків гріхопадіння, і $є$ необхідним елементом життя в зіпсованому гріхом світі, в якому особистість і суспільство потребують захисту від небезпечних виявів гріха. Отже, держава $\epsilon$ інститутом, покликаним захищати права та інтереси й окремої особи, і суспільства загалом від гріховних, тобто позазаконних зазіхань на них із будь-чийого боку. Однак історичний досвід свідчить, що дуже часто державна влада не тільки не виконує покладеної на неї функції захищати своїх громадян від гріховних посягань, а й сама стає символом несправедливості, порушуючи права народу. У такий спосіб християнське світосприйняття стає вирішальним чинником для цілком нового, інакшого, аніж в античності, розуміння свободи. Фактично, ми ототожнюємо свободу зі свободою волі, що не було властиво давньогрецькій філософії. Там свобода мала лише прикладний характер до того, що вважалося субстанційною основою дії або активності. «Метафізика» Аристотеля зосереджувалася на виявленні сутності, форми чи природи речей.

Найочевиднішою ознакою громадянського статусу особи $\epsilon$ наявність свободи як ії атрибутивної властивості. Оскільки всі люди, згідно 3 християнським ученням, мають рівні «вільні волі», то громадянське суспільство - це такий соціальний проект, що може здійснюватися лише на двох рівнях життя: політичному та позаполітичному (на рівні християнської громади і церковної організації). Обгрунтуванням такої думки можуть бути міркування св. Томи Аквінського про те, що «поняття «найвище благо» в приватному і громадському житті - одне й те саме» ${ }^{3}$.

3 Аквінський Т. Коментарі до Арістотелевої «Політики». Київ: Основи, 2000. C. 702. 
Під впливом християнського вчення св. Тома Аквінський інтерпретує природу державно-політичної влади дещо інакше, ніж Аристотель ${ }^{4}$. Насамперед це стосується визначення суспільного місця людини, якій Богом дарована вільна воля, - вона від народження підпорядкована Богові. Посередництво між індивідом, Небом і світом (державою) здійснюється завдяки добровільно утвореним громадам. Індивід не може цілком підпорядковуватися політичній владі. Його підпорядкування визнається лише в межах тих політичних зв'язків, де може бути збережена самостійність або міра свободи, достатня, щоби добровільно відійти від світу марноти, дистанціюватися від влади, яка загрожує поглинути людське сумління. Звідси відраза Томи Аквінського до середньовічного деспотизму й неприйняття будь-яких форм «політичного тоталітаризму». Держава як громадянська спільнота, в інтерпретації Томи Аквінського, виникає як стандарт якогось типу поведінки іï учасників. Основною ознакою тут стає здатність людей чи груп людей, жорстко організованих, переступати межі матеріальних залежностей і прямувати назустріч людині іншої групи: сімейної, майнової, етнічної, політичної - сприймати чужинця не як ворога, а як собі рівного, ближнього, що цілком узгоджується 3 основними християнськими принципами. Чимало уваги під час дослідження природи влади $\mathrm{i}$ держави християнські філософи приділяли ролі людини як особистості, а отже, важливості для соціального розвитку народу створення іiї еліти, основу якої повинні становити християни. Ці погляди мислителі розвивають через такі фундаментальні поняття соціальної філософії, як суспільство, суспільне буття, суспільні відносини, соціальна структура, влада. У такий спосіб визначено типи еліти як соціальний феномен громадянського суспільства та ії місце в системі суспільних відносин.

У загальному, Середньовіччя, 3 огляду на проблему, що розглядається, характеризується передусім відсутністю єдиної управлінської системи, яка мала би всю повноту влади в тогочасному суспільстві. Таку думку підтверджує американський учений, фахівець 3 історії середньовіччя Б. Тірні. Він зазначає, що «у середньовіччі ніколи не було єдиної управлінської ієрархії, яка би здійснювала необмежену владу; натомість було дві - церква і держава, як ми кажемо сьогодні, що часто змагалися між собою, обмежуючи владу одна одної» 5 .

4 История политический и правовых учений: учебник / под ред. К.И. Мордвинова. СПб.: Питер, 2002. 435 с.

${ }^{5}$ Tierney B. The Crisis of Church and State, 1050-1300. N. Y., 1964. P. 67-68. 
У процесі зміцнення, головним чином, матеріалістичних позицій у світобаченні в цей час простежується явище секуляризації (латин. saecularis), тобто зміни у взаємовідносинах релігії із суспільством у напрямі звільнення від релігійного впливу, та секуляризму відвернення від релігії як такої в суспільстві, сім'ї, політиці тощо. Звичайно, це призводить до значного зменшення ролі релігії в політичному, соціальному та особистому житті, а також уведення принципу світськості в суспільне життя. Надзвичайно гостро у XVII ст. ця проблема постала в Англії, оскільки тема свободи і природних прав людини та зміни принципів формування державної влади розвивалася навколо суперництва королівської влади і повноважень Парламенту. Зрештою, заперечуючи теологічне пояснення історичного процесу, прибічники теорії суспільного договору утверджували раціоналістичні концепції природи суспільства. Проте ці концепції грунтувалися на позаісторичних уявленнях про незмінну сутність людини, нерозумінні закономірного процесу розвитку людства. Спроба ж поширити принцип детермінізму (загальної причинової зумовленості явищ) на пояснення суспільних явищ не давала можливості збагнути секрети людського буття, його специфічної упорядкованості.

Доцільно відзначити, що в епоху Нового часу і Просвітництва відбувається інституалізація форм суспільного впливу політики та релігії, вони відокремлюються більше одна від одної, філософи і теологи намагаються визначити межі їхньої взаємодії та взаємовпливу, оскільки політика, право і теологія представляють, генерують і транслюють різні соціальні та культурні зв'язки суб'єктів, визначають міру долучення їх до процесу побудови та функціювання суспільства, держави, хоча найчастіше вони й далі грунтуються на одних і тих самих здобутках культури, систем норм, цінностей, значень. Релігійна і світська філософія аналізованого періоду дала змогу за основу християнського світогляду взяти антропологічну доктрину - вчення про людину, зміни в якій відображають соціальнокультурні трансформації цієї епохи. Одним із найбільш значущих інструментів формування конфесійної самосвідомості стає соціальна доктрина церкви, яка відображає трансформації конфесійних уявлень про місце і роль християнина у світі відповідно до «виклику часу».

Тема переосмислення ролі держави і релігії в суспільстві та забезпечення його життєдіяльності постає надзвичайно гостро в сучасній європейській філософії, оскільки саме в цей час починає формуватися демократичне розуміння людини та ії природних прав, які лежать у площині відносин «людина-суспільство-держава», 
а також формування релігійної свободи та релігійних прав, що проектуються у площину відносин «людина-церква - держава». Значний вплив на цей процес мав і рух християнської філософії в цей час до побудови християнської концепції суспільства здебільшого на персоналістських принципах, на що особливо відгукнулося тогочасне суспільство, яке гостро відчувало відчуження та дегуманізацію людської особистості під впливом науково-технічного прогресу. Зміна руху філософської та богословської думки у свою чергу викликала появу у філософії нових ірраціоналістичних напрямів, які проблему людини та iï самореалізації почали розглядати в абсолютно іншому ракурсі. Відповідно до ірраціоналістичного тлумачення визначальним аспектом духу вважаються позамислені процеси: уявлення, почуття, інтуїція, воля тощо. Як відомо, найважливішими складниками духу є імперативи, поведінка, що випливають 3 уявлень, або 3 яких випливають самі уявлення. Імперативи формують ядро духу, найважливішу його частину; окрім того, дух інколи набуває форми, коли в ньому взагалі панують лише імперативи (мораль, релігія), але ніколи не буває так, що дух існує або діє без імперативів. Матеріальний розвиток суспільства (порівняно з іншими історичними епохами), його спрямованість на механіцизм, можливу втрату людиною власного майбутнього «Я» призвів до того, що одним із найважливіших аспектів поширеного процесу модернізації філософії та християнства, відповідно до тогочасних вимог, стає звертання до проблеми людини. Зосереджуючи увагу на питаннях про глибинну сутність людини, iї роль у Всесвіті, суспільні обов'язки, цілі та сенс існування, релігійна філософія намагається обгрунтувати тезу, що виключне право у розв'язанні основних проблем людського буття належить саме релігії.

У сучасній європейській філософській думці значну увагу приділено вивченню процесу розвитку людини в суспільстві, іï прав i свобод у громадянському суспільстві. Незважаючи на розвиток науки, техніки, культури, відносини людини і релігії і надалі є однією із центральних тем антропологічної, релігійної філософії, філософії культури та інших напрямів філософії. Нове трактування важливості релігії та іiі роль у культурному житті людини, виборювання власних прав і свобод створюють новий вимір щодо інтерпретації їхньої природи. Отже, у філософському руслі сучасної європейської філософії відбувається подальша переорієнтація «модерністських» неортодоксальних релігійних філософів на антропоцентризм, що полягає не в офіційному перегляді філософських напрямів та релігійних догм, 
а в умовному немовби відокремленні філософії від теології. Не переглядаючи традиційної «ієрархії проблем», сучасні релігійні філософи висувають у центр своїх досліджень етичні, антропологічні, соціальні, соціально-правові питання. Найбільшою мірою в цьому аспекті оновлення торкнулося проблеми взаємовідносин між релігією, релігійною філософією та наукою, державою i церквою. Інакше кажучи, розуміння церквою особливостей формування i розвитку людської особистості в сучасному світі та намагання проникнути в проблеми людини, вибудувати на цій основі систему релігійного права слугують каркасом для налагодження відносин між державою і церквою, церквою та громадянами.

\section{2. Екзистенційність людини крізь призму релігійної герменевтики суспільства та влади}

Тема переосмислення ролі релігії у формуванні людини як особистості та забезпечення iї природних прав постає надзвичайно гостро в сучасній європейській філософії. Сучасне розуміння свободи і прав людини, зокрема релігійної свободи i релігійних прав, сформувалося в перші десятиліття після Другої світової війни. Державно-суспільні відносини завжди були важливим компонентом розбудови суспільства. Під державно-релігійними стосунками треба розуміти сформовану на основі загальноприйнятих норм, звичаїв та законів взаємодію державних чинників (особливо законодавчої і виконавчої влади) та складників релігійного комплексу. Урегульований характер таких стосунків між різними суб'єктами соціуму, а також окремими громадянами і суспільними групами, $\epsilon$, значною мірою, запорукою спокійної соціальної ситуації, що допомагає державі та іiі суспільству уникнути потенційних конфліктів, і не тільки на релігійному грунті. Загальнолюдські ідеали, такі як соціальна справедливість, демократія, свобода особистості тощо, безперечно, $\epsilon$ позитивними поняттями, надбанням культурноцивілізаційного процесу людства. Однак ці чесноти можливі лише за умови, що людина насамперед духовно оберігає свою душу, свій внутрішній світ через серйозно продуману систему духовного виховання в суспільстві. Крім того, духовно-релігійна сфера національних інтересів безпосередньо пов'язана 3 дією механізмів самозбереження нації, держави та зі створенням максимально сприятливих умов для іiі цивілізованого розвитку. Необхідною умовою розбудови демократичної держави $є$ те, що національні інтереси, особливо в духовно-релігійній сфері, повинні визначатися лише 
волевиявленням народу безпосередньо або через вищі інституції державної влади. Більше того, якщо роль держави у формуванні особистості визначена вже давно, практичні заходи щодо формування світогляду людини реалізуються системою державної і суспільної освіти та виховання, то місце релігії в цьому процесі в сучасному світі і в Україні зокрема постійно зазнає змін відповідно до авторитету церкви та релігійних діячів, суспільних традицій і настроїв, а інколи й політичних моментів у той чи інший історичний момент часу.

Загалом, навіть зараз ще недостатньо вивчено закономірність взаємозв'язку релігії і держави через ті функції, які вони реалізують у суспільстві. Генеза співпраці держави і релігії в демократичних умовах сьогодення 3 усією очевидністю виявляє в них появу своєрідного «інстинкту самозбереження», вираженого в необхідності забезпечення стабільності наявної системи. I політична, і релігійна системи намагаються забезпечувати суспільну стабільність, а отже, функції i релігійних, і політичних (як державотворчих) систем, спрямовані на формування суспільної ідеології, об'єднання суспільства, забезпечення правопорядку й безпеки за сприятливих умов, збігаються, забезпечуючи стабільність суспільства, внутрішню безпеку держави. Під час аналізу впливу релігії на дійсність можна простежити, як іiі світоглядна чи змістожиттєва функція реалізується через систему поглядів на природу суспільства і людини. Як наслідок, будь-який суспільний і державний устрій передбачає одночасно наявність, 3 одного боку, системи правових норм, що реалізуються органами примусу (армія, суд, прокуратура, спецслужби тощо), 3 іншого системи моральних установок, що змушують людей виконувати і поважати закони. Як відзначав Д. Белл, «за всеохоплюючого нормального порядку виправдання справедливості таких норм коріниться в системі цінностей, що розділяються людьми» ${ }^{6}$. Отже, релігія виступає в соціумі як соціальна підсистема та самостійна система $з$ деякою структурою, основу якої становлять ідеї, погляди, уявлення, цінності, відповідна поведінка, специфічні дії (культова діяльність), що виходять за межі соціального та належать до трансцендентного. Якщо сутність людини в суспільстві та світі в широкому розумінні лежить у площині відносин «людина суспільство-держава», то вплив релігії, релігійної свободи та релігійних прав людини зазвичай проектуються у площину відносин

6 Bell D. The Cultural Contradiction of Capitalism. N. Y., 1976; Пер. А.К. Оганесяна в кн.: Етична думка. Москва,1990. С. 251. 
«людина - церква - держава», що, на нашу думку, вимагає пошуку найбільш загальних закономірностей розвитку багатогранної особистості, а отже, і з'ясування причин, які впливають на динаміку відносин таких суспільних інститутів, як церква і держава. Адже і держава, і релігія та церква як інституція релігії $є$ суспільними феноменами.

Релігійна система охоплює світорозуміння (пояснення світу загалом, окремих явищ і процесів у світогляді, відображення світу у відчуттях і сприйняттях), віровідчуття (емоційне сприйняття чи несприйняття), світовідношення (оцінка) тощо. У ролі їі підсистеми виступає «перетворювальна діяльність», кінцевим результатом якої $\epsilon$ мислене, ідеальне, віртуальне перетворення світу, формування у свідомості його відображеної картини, ідеалів, принципів, ціннісних установок тощо, які сукупно становлять релігійне світобачення. Останнє задає абсолюти, «кінцеві критерії», 3 урахуванням яких сприймається й осмислюється Всесвіт, суспільство, людина. Формуючи у свідомості людини картину світу, релігійний світогляд сприяє осмисленню вірянином цієї картини, набуттю ним змісту життя. Отже, релігія породжує і підтримує надію в тих, хто вірує, вирватися за межі обмеженості, позбавитися від проблем буття, страждань, лиха, самотності, морального падіння, розчарування в колишніх ідеалах.

Осягнення змісту життя i подій, що відбуваються навкруги, допомагає людині долати життєві негаразди, що випали на ії долю. Тому що негаразди і випробування, навіть сама смерть для вірної людини наповнені особливим змістом. Ураховуючи, що віряни $\epsilon$ органічною частиною суспільства, причому значною, є підстави стверджувати про те, що релігія може виконувати функції, які забезпечують формування і зміцнення суспільної солідарності та стабільності. Так, шляхом культу релігія констатує спільноту вірних як єдиний організм: готує вірянина до виконання моральних норм соціального життя, виховує послух, підтримує традиції. У цьому випадку функції релігії аналогічні за своєю спрямованістю функціям держави, яка $\epsilon$ не релігійною, а політичною формою організації суспільства.

Взаємодія релігії і держави є об'єктивним, закономірним процесом еволюції релігійних і політичних, соціальних і державотворчих систем. Відповідно, церква - не просто релігійний інститут, це інститут, що перебуває в системі політичних, соціокультурних відносин. Впливаючи на формування окремої особистості, релігійної громади, 
релігія сприяє цілісності суспільства, оскільки багато аспектів іiі виховно-культурних та охоронно-правничих функцій є подібними до функцій держави.

Закріплення і розвиток національних ментальних структур вимагає насамперед формування власної глибинної системи духовно-релігійної орієнтації, україноцентристської моделі світу, тобто того особливого підходу, який дозволяс спиратися на самодостатні судження про речі та події у світі. Подібно до внутрішнього «Я» особистості, нація також повинна самоусвідомлюватися і мати власні структури вірувань, звичаїв та ціннісних орієнтацій, що грунтуються на власному історичному досвіді.

Заразом нація - це певний організм, що складається 3 реальних особистостей, кожна 3 яких має ексклюзивні бажання і прагнення. Завдання держави полягає в тому, щоб забезпечити прогресивний розвиток нації загалом, не пригнічуючи при цьому життєвих інтересів окремих громадян, релігійних організацій чи соціальних груп. За таких умов окремі системи вірувань у свідомості нації набувають ознак збалансованої рівноваги серед решти духовно-релігійних складників суспільства. Необхідною умовою такої рівноваги постає соціально привабливий загальнонаціональний центр тяжіння. Таким центром має стати українська духовно-релігійна ідея. Тому релігійну свободу і релігійні права зараховують до найвагоміших чинників, які впливають на відносини між такими суспільними інститутами, як держава і церква. Релігійні права зароджуються разом із зародженням християнства як реалізація властивих йому ідей людської свободи і любові.

Отже, виникаючи на якомусь етапі історичного розвитку, релігія бере активну участь у побудові світу ідеальних сутностей, що на практиці веде до обгрунтування пріоритету духу над тілом. Зі свого боку, християнська релігія вкорінюється в національний грунт, як наслідок, i національна, i європейська культура загалом часто набувають релігійного забарвлення. Специфічна комбінація цих чинників додає і культурі, i релігійності нації неповторних рис, а суб'єктам культури - усвідомлення своєї національної належності ${ }^{7}$. Заразом релігійна мораль, яка грунтується на загальнолюдських цінностях, стає основою суспільної моралі цивілізації, відповідних

7 Бодак В. Релігія і культура: взаємодія та взаємовплив. Київ; Дрогобич: Коло, 2005. С. 201. 
суспільних цінностей, які у свою чергу відображаються в етичних нормах поведінки громадян, державних службовців також.

Останніми десятиріччями вплив релігійного життя на суспільство не тільки не зменшується, а й надалі зростає, трансформуючись у релігійні права сучасної людини. Як зазначає один із провідних дослідників цієї проблематики Б. Тірні, «навіть на Заході вчення про релігійні права з'явилося досить пізно, долаючи опір традиції, яка перед тим безболісно сприйняла інші права людини» ${ }^{8}$. Тож релігійні права, з погляду історичної перспективи, утвердилися найпізніше i виявилися найважчими для сприйняття i найскладнішими щодо втілення в суспільну практику. Загалом, проблематика впливу релігії на формування особистості та іï свідомості і взаємодія в цьому питанні 3 державною владою має найбільше відношення до проблеми відносин церкви i світу. Вирішення цього питання зумовлено в кожній християнській традиції досвідом церковно-державних відносин. Православна церква подібно до католицької завжди була міцною інституцією. Але як національна церква вона завжди безпосередньо залежала від світської влади. Отже, іiі інституціональний вплив був великим, але можливість вільної політики - обмеженою, що підривало авторитет церкви як соціальної інституції. 3 іншого боку, православ'я, як i протестантизм, спираючись на чіткий розподіл духовних і соціальних «речей» i концентруючись на духовних, має великі можливості впливу на окремого індивіда в соціально-моральному вимірі. Однак і тут державна залежність стає на перешкоді, щоб мати власну, відмінну від державної, ідейну концепцію.

Світове співтовариство багато робить i в інформаційному, і в законодавчому плані для того, щоб функціювання релігії в державі сприяло гармонізації модельних відносин, а не дезінтегрувало людей. Серед найбільш значних і відомих проектів можна назвати освітні програми країн Свросоюзу, які передбачають поширення об'єктивної та всебічної інформації про наявні релігії та права людини; зміни в законодавстві окремих країн щодо статуту релігійних організацій. Однак для науки державного управління вагоме значення має вивчення загальних закономірностей, особливо коли йдеться про взаємодію держави і церкви. Моральний сенс існування держави, як про це вчить Святе Письмо [Рим. 13, 3-4], полягає в тому, щоб за потреби використовувати силу для обмеження зла і підтримки добра. Церква

${ }^{8}$ Tierney B. The Crisis of Church and State, 1050-1300. N. Y., 1964. 136 p. 
тут виступає як інституція, суспільна структура, яка має захищати дух людський, дух гуманізму та суспільних чеснот.

Основними державотворчими принципами сучасної демократичної держави є забезпечення кожному громадянинові права на свободу світогляду і віросповідання. Це досягається завдяки охороно-правничій функції держави, реалізація якої полягає у приведенні суспільства до громадянського миру, зміцнення національної єдності, захисту національних інтересів. Підгрунтям такої політики має бути досконала правова база взаємин держави і церкви та юридичне оформлення функціювання релігійних організацій.

Зростання значущості індивіда в релігійному житті, ваги в релігійному світобаченні саме його особистої віри привело до зміни в релігійних системах традиційної для богословського вжитку релігійної картини світу на картину людини в соціумі, де людина 3 позицій Бога, а саме відповідно до Десяти Заповідей Господа Бога, осмислює своє існування та життєдіяльність. У суспільному житті, де відчутні наслідки глобалізації, що ведуть до перетворення людства на єдиний планетарний організм, релігія сприяє усвідомленню єдності й цілісності життя як такого. Тут релігія висуває максиму, найвищу вимогу, відповідно до якої оцінюються події і явища та формується ставлення до них. До того ж максимі надається безумовний, обов'язковий характер. Для стабільного існування спільноти вірян, суспільства і держави всі громадяни повинні дотримуватися і певних форм поведінки. Йдеться не лише про регламентацію й виконування тих чи інших культурних, релігійних, суспільних, правових звичаїв, порядків і норм, а про внутрішньо осмислене ставлення до них: чи допустимі вони як такі. Інакше кажучи, якщо припустити, що ці порядки й норми є продуктом діяльності людини і суспільства, то потрібно визнати їхній відносний характер, можливість їх зміни разом з умовами навколишнього середовища. Якщо ж погодитись, що звичаї, порядки й норми мають надлюдську природу, $\epsilon$ вічними, абсолютними, то релігія виступатиме базовою системою не тільки окремих звичаїв, порядків і норм, а всього морального устрою, всієї морально-етичної системи суспільства й особистості. Тісно пов'язані $з$ наведеними вище чинниками впливу світоглядно-ціннісні характеристики українського народу, що також позначаються на особливостях державного устрою та системі державно-владних відносин.

Розглядаючи світогляд як сукупність поглядів, оцінок, норм та установок, що визначають ставлення людини до світу і виступають 
у ролі орієнтирів та регуляторів його поведінки 9 , треба аналізувати його вплив у комплексі з такими категоріями, як суспільні цінності та релігійні переконання. Суспільні цінності - це загальноприйняті переконання відносно цілей, яких людина повинна прагнути, і які становлять основу моральних принципів. Цінності, які $\epsilon$ ядром культури, суспільство формує поступово, через відбір певних видів поведінки і досвіду людей. 3 часом ці види поведінки закріплюють, схематизують у таких нормативних утвореннях, як традиції, обряди, звичаї та ритуали. У подальшому ціннісні взірці зберігаються і передаються через соціальні інститути, набуваючи змін залежно від змін суспільного устрою, ідеалів та цілей людської життєдіяльності. При цьому варто зазначити, що цінності громадян - державних службовців - загалом відповідають головним орієнтирам доброчесності, що охоплюють істину, добро, красу, людську гідність, свободу, честь, справедливість і відповідальність.

На сучасному етапі вплив релігії на формування особистості в українському середовищі багато в чому зумовлюється соціальнополітичною стабільністю в Україні соціально-релігійних відносин, змістом та спрямованістю державно-церковних i міжконфесійних відносин, суспільною активністю релігійних інституцій та традиційною культурною терпимістю українського народу відносно інших культур та віросповідань. Амплітуда окремих варіантів розбудови стосунків між державою та релігійними організаціями досить широка, i кожен конкретний випадок зумовлений ходом історичного процесу, територіальним положенням країни, соціальною активністю на іiі теренах релігійних груп тощо. При цьому можна вважати, що міжнародне право пропонує різні підходи, схильні і до сепарації, і до кооперації у взаєминах між державою та церквою. Міжнародне право стосується насамперед засад особистої свободи совісті, а не конкретних моделей державно-церковних відносин, залишаючи останні на врегулювання окремим державам.

Проте з уваги на об'єктивні зміни в релігійній парадигмі, які відображають зміни в соціально-економічному, політичному, культурному та ідеологічному житті суспільства, які зумовлюють секуляризацію масової свідомості, можна стверджувати, що в сучасному глобалізованому світі релігійність стає справою індивідуального і довільного вибору особистості. Основними

9 Кононенко Б.И. Большой толковый словарь по культурологи. Москва: Вече-2000; АСТ, 2003. С. 269. 
чинниками такого процесу в умовах зміни парадигм людського мислення стають масова секуляризація суспільної свідомості, науковотехнічна та інформаційна революція, соціальні й екологічні катаклізми, що змушують і сучасне християнство відповідати на виклики часу, шукати і пропонувати людині новітні духовні засади їі життя, що допоможуть їй знайти власне «Я» у стрімко змінюваному світі. Зворотний вплив релігії на внутрішньодержавні відносини найбільш помітно виявляється у формуванні та участі громадян-вірян у політичному й суспільному житті країни. Адже політика як феномен пронизує всі сфери суспільного буття, у такому разі справжній християнин не може бути поза політикою як суспільним явищем, що пов'язане $з$ кожною людиною.

Теоретичний рівень релігійної свідомості завжди мав і має прямий вплив на формування чи обгрунтування політичних устроїв, суспільнополітичних відносин, пов'язаних із проблемою публічної влади. Натепер релігійний вплив - це складна система взаємодії та взаємовпливів канонічно й організаційно структурованих церковних інституцій, релігійних та світських традицій українського народу, вплив західних та східних традицій, що значно зростають у зв'язку із глобалізацією світової економіки, відкритістю українських кордонів та зростанням культурно-освітніх взаємообмінів, трудовою міграцією населення. Ця система суспільних взаємозв'язків є обов'язковим складником суспільного життя України, чутливо реагує на утвердження в суспільній свідомості загальнолюдських цивілізаційних демократичних цінностей, світоглядних, національних ідей, моральноетичних принципів, власних позицій у витлумаченні національної та релігійної історії.

\section{ВИСНОВКИ}

Як соціокультурне явище, що стосується вищих сфер людської духовної діяльності 3 формування свідомості та світосприйняття людиною самої себе i навколишньої дійсності, емоційності, раціональності й ірраціональності іï багатогранного життя, релігія займає активну позицію щодо функціонування суспільства, характеру культури, культурно-інформаційних обмінів. Тож, впливаючи на духовні процеси, вона пов'язана зі збереженням та розвитком традицій у суспільстві, духовністю і культурою, ментальністю та національною самосвідомістю народу, а отже, знаходженням шляхів для кращого самоусвідомлення і формування внутрішніх підвалин, демократизації та культуризації соціуму. Реалізація принципів гуманізму, релігійної 
свободи та забезпечення релігійних прав сьогодні є справою дуже складною, оскільки в релігійному житті українського суспільства виявились і постійно зміцнюються суперечливі тенденції, пов'язані 3 появою та поширенням у нашій державі новітніх, не укорінених у традицію і ментальність населення релігійних культів. Ця актуальна конфліктогенна проблема вимагає всебічного дослідження 3 боку юристів, а також визначення легітимних засад для подальшої дії фахівців у справі налагодження громадянського та міжконфесійного миру.

\section{АНОТАЦІЯ}

Почуття втрати сенсу може виникати від експлуататорської політики деяких держав, де людина почувається обманутою, скривдженою, просто коліщатком в якомусь великому механізмі. Відповідальність за такий стан речей лежить на тих, які, маючи владу, керуються бажанням щораз більшого збагачення, ведуть країну до екзистенційної безвиході, де дедалі більше людей починають відчувати втрату сенсу. Відповідно, за критичної кількості таких людей безпека країни, щонайменше, не стане кращою. Власне, в такій ситуації тісна співпраця між державою і церквою як екзистенцією християнської релігії дає шанс тому, що керівниками держави зокрема і суспільства загалом будуть ураховані застереження проти небезпеки буття як такого, й особливо буття в суспільно-політичному вимірі без огляду життя на духовно-аксіологічні принципи трансцендентального виміру.

\section{ЛІТЕРАТУРА}

1. Аверинцев С. Софія-Логос : словник. Київ : Дух і Літера, 2007. $650 \mathrm{c}$.

2. Аквінський Т. Коментарі до Арістотелевої «Політики». Київ : Основи, 2000. 794 с.

3. Арендт Г. Між минулим і майбутнім. Київ : Дух і Літера, 2002. $322 \mathrm{c}$.

4. Бліхар В.С. Державно-церковні відносини як експлікація дихотомії влади та суспільства у європейській філософії : монографія. Львів : ЛьвДУВС, 2013. 516 с.

5. Бліхар М.М., Ковалів М.В., Гаврильців М.Т. Конституційне право України : навчальний посібник. Львів : Ліга-прес, 2014. 402 с.

6. Бодак В. Релігія і культура: взаємодія та взаємовплив. Київ ; Дрогобич : Коло, 2005. 306 с. 
7. Габермас Ю. Структурні перетворення у сфері відкритості: дослідження категорії громадянське суспільство. Львів : Літопис, $2000.318 \mathrm{c}$.

8. Гумбольдт В. фон. Позитивна і негативна держава. Лібералізм : антологія / упоряд. О. Проценко, В. Лісовий. Київ : Смолоскип, 2009. C. 649-651.

9. История политический и правовых учений : ученик / под ред. К.И. Мордвинова. Санкт-Петербург : Питер, 2002. 435 с.

10. Кононенко Б.И. Большой толковый словарь по культурологии. Москва : Вече-2000 ; АСТ, 2003. 512 с.

11. Лобье П. де. Социальная доктрина Католической Церкви: опыт воплощения христианского идеала. Брюссель, 1989. 254 с.

12. Tierney B. The Crisis of Church and State, 1050-1300. New York, 1964. $136 \mathrm{p}$.

13. Bell D. The Cultural Contradiction of Capitalism. New York, 1976.

\section{Information about authors:}

Blikhar V.S.,

Doctor of Philosophical Sciences, Professor, Head of the Department of Philosophy and Political Science

Lviv State University of Internal Affairs 26, Horodotska str., Lviv, Ukraine

Blikhar M. M.,

Doctor of Juridical Sciences, Associate Professor, Associate Professor of the Department of Constitutional and International Law

Institute of Jurisprudence and Psychology of the Lviv Polytechnic National University 1/3, Knyaz Roman str., Lviv, Ukraine 